\title{
Türkçe atasözü ve deyim hazinesine Atalar Sözü Mecmuası'ndan' katkılar
}

Ensar ALEMDAR ${ }^{2}$

\begin{abstract}
APA: Alemdar, E. (2019). Türkçe atasözü ve deyim hazinesine Atalar Sözü Mecmuası'ndan katkılar.
\end{abstract} RumeliDE Dil ve Edebiyat Araştırmaları Dergisi, (Ö5), 112-124. DOI: 10.2900o/rumelide.606080.

$\ddot{O} \mathbf{z}$

\begin{abstract}
Atasözleri ve deyimler, bir milletin tecrübelerini âdeta bir öz hâlinde ihtiva eden kültür mirasları olduğu gibi aynı zamanda kelimelerin anlam inceliklerini de bünyelerinde barındıran dil zenginlikleridir. Zamanla bazı yeni kelimeler türediği gibi bazı kelimeler de unutulabilir; ancak dilden dile dolaşan ve hemen hemen her edebî eserde karşımıza çıkan atasözleri ve deyimlerin muhafazası, bu unutulmayı en aza indirmemizi sağlayacaktır. Ayrıca, bazı kelimelerin anlamları unutulsa dahi eğer söz konusu kelime bir atasözü veya deyimde yaşıyorsa, atasözleri ve deyimlerin yukarıda zikredilen hususiyetlerine binaen, zamanla o kelimenin anlamı da hatırlanabilecek ve kelime geri kazanılabilecektir. Zikredilen bu hususlara bir örnek, günümüzde 'devir değişti, eski tutumların değeri kalmadı' manasında kullanılan "Eski çamlar bardak oldu.” ibaresinin 'çamdan yapılan su testisi' manasındaki bardak kelimesinin bahse konu anlamını muhafaza etmesidir. Bununla birlikte; her bir atasözü ve deyim, haiz olduğu hususiyetleri ancak kullanıldığı sürece yerine getirebilir. Bu sebeple, atasözleri ve deyimlerin unutulmamasına ve kullanımlarının daha da yaygınlaşmasına yönelik çalışmaların yapılması gerekmektedir. Bu anlamda, atasözleri ve deyimler konusunda bugün yapılması gereken en mühim çalışmalardan biri de bu alanda geçmişte yazılmış eserleri günümüze kazandırmak olacaktır. Aslında, Osmanlı döneminde yazılmış eserlerden pek çoğu birçok çalışmada kaynak olarak zikredilmiş ve bu eserlerden bir kısmı üzerine müstakil çalışmalar da yapılmıştır. Çalışmamıza konu olan Çelebioğlu Abdülhalim Hakkı'nın Atalar Sözü Mecmuası eseri ise birkaç kaynakçada künyesi kaydedilmiş olmakla birlikte ne yazık ki bu ilgiden mahrum kalmıştır. Bu çalışmada, atasözleri ve deyimlerle ilgili hâlihazırdaki kaynaklarda bulunmayıp Atalar Sözü Mecmuası'nda yer alan ve mevcut kaynaklardakilerden farklı biçimleriyle kayda geçen bazı atasözleri ve deyimler üzerinde durulmuştur.
\end{abstract}

Anahtar kelimeler: Atasözü, deyim, derleme, Osmanlı Türkçesi, Çelebioğlu Abdülhalim Hakkı.

\section{Contributions from Atalar Sözü Mecmuasi to the treasure of Turkish proverbs and idioms}

\begin{abstract}
Proverbs and idioms are the richnesses of language that host the subtleties of words' meanings in themseles at the same time as containing within their essential state the experiences of a nation that are its cultural heritage. Some words can also be forgotten with time as certain new words spring up; only the preservation of proverbs and idioms allows us to minimize this forgetting. Additionally, even if the meaning of some words are forgetten, if these words live on in a proverb or idiom, the meaning of these words can also be remembered and regained to these words with time by virtue of the intimacies intoned in these proverbs and idioms. One example of these intoned particularities, "Eski

\footnotetext{
$1 \quad$ Bu eserin giriş kısmından elif maddesinin sonuna kadar olan 614 sayfası, tarafımızdan Prof. Dr. Mustafa S. KAÇALìn yöneticiliğinde doktorluk tezi olarak çalıșılmıștır.

2 Öğr. Gör., Dr. Kırklareli Üniversitesi, Türk Dili Bölümü (Kırklareli, Türkiye), ensaralemdar@gmail.com, ORCID ID: 0000-0002-0682-5594 [Makale kayıt tarihi: 12.06.2019-kabul tarihi: 18.08.2019; DOI: 10.29000/rumelide.606080]
}

Adress

Kirklareli University, Faculty of Arts and Sciences, Department of Turkish Language and Literature, Kayalı Campus-Kirklareli/TURKEY e-mail: editor@rumelide.com
\end{abstract}


çamlar bardak oldu." which is used these days in the sense of 'times have changed and old attitudes don't retain their value,' is the preservation of the subjected meaning of the word bardak in its meaning from the phrase 'water jug made from pine.' However, any proverb or idiom is able to fulfill the intimacies it posseses only as long as it is used. Therefore, studies should be perfomed on not forgetting proverbs and idioms and also on having their usage become more widespread. In this sense, one of the most momentous studies that need to be perfomed today on the issue of proverbs and idioms also would redound works written in the past in this area to our day. In fact, works written in the Ottoman period have been intoned as resources in many a study, and independent studies have also been performed on a portion of these works. Atalar Sözü Mecmuası, the work of Çelebioğlu Abdülhalim Hakkı and the subject of our study, although being catalogued in several reference lists, has unfortunately been deprived of this interest. This study focuses on the some of proverbs and idioms contained in the Atalar Sözü Mecmuası that have not yet been found in reference lists on proverbs and idioms but that have been recorded in various forms from what is in available sources.

Keywords: Proverb, idiom, compilations, Ottoman Turkish, Çelebioğlu Abdülhalim Hakkı.

\section{Giriş}

Eğitimle fertlere verilmeye çalışılan değerlerde milletlere göre bazı farklılıklar olsa da "eğitimin; dünü koruyup tanıtma, bugünü kavratma ve yarınlara güven içinde hazırlama gibi üç esas yönü (TEZCAN: 1992, 9)" bulunmaktadır. Zikredilen bu eğitim esaslarının hayata geçirilebilmesi için, eğitimde kullanılan eserlerin mahiyetinin de bahse konu olan esaslara muvafik olarak tertip edilmesi elzemdir. "Ders kitabı, çocuğun yaşadığı toplumla bütünleşmesini sağlayan, o toplumun inançlarını, kültürünü, yaşam biçimini, felsefesini, etkileşme biçimlerini, gelenek ve göreneklerini açıklayan ve ilk öğreten kaynaktır (DEMIREL-KIROĞLU: 2005, 45).” Dolayısıyla; dil öğretiminde kullanılan ders kitapları, sadece ele alınan herhangi bir konunun öğretildiği eserler değil aynı zamanda bahse konu dili konuşan toplumun tanıtıldığı kaynaklardır ve bu sebeple bu kaynaklar, hem muhtevaları hem de dil özellikleri ile milletin değerlerini fertlere en iyi şekilde aktarabilecek metinlerden oluşturulmalıdır. Bu metinlerin derlenebileceği en önemli memba ise kısaca "hem muhtevaları hem de dil özellikleri ile yazıldığı dönemden itibaren örnek alınan ve değerini kaybetmeyen eserler (ÖZDEN: 2010, 168)” şeklinde tarif edilebilecek kaynak metinlerdir.

Bir ağacın meyve verebilmek için kökleriyle topraktan beslenmesi ve yapraklarıly hava ile güneşten istifade etmesi gerektiği gibi bir milletin geleceği olan fertlerin de yetişebilmek için milletinin mazisinden beslenmesi ve bugünkü değerlerden istifade etmesi gerekmektedir. Bir ferdi milletinin mazisiyle buluşturan; millet ve fert arasında bağlar tesis eden; millî birikimi ferde, ferdî birikimi millete taşıyan ve bu sayede ferdi milletin bir parçası yapan en önemli unsurlardan biri o milletin kaynak metinleridir. Dolayısıyla bu eserler, sadece fert ve millet arasındaki bağı tesis etmesi ile değil aynı zamanda ferde kendisini tanıtması yönüyle de mühimdir.

Dil öğretimi ve kültür aktarımı iç içedir. Dolayısıyla, kültür aktarımının eğitimde en önemli unsuru olan kaynak metinler, aynı zamanda dil öğretiminin de en mühim yardımcılarıdır.

Türkçenin elimizdeki en eski yazılı metinlerinden itibaren hemen hemen her eserde az veya çok karşımıza çıkan atasözleri ve deyimler de ders kitaplarında yer alması gereken, yukarıda zikredilen hususiyetlere sahip en önemli yardımcı kaynaklardandır; zira atasözleri ve deyimler, kaynak metinlerde sıkça karşılaşılabilen yapılar olmalarının yanı sıra aslında, her ne kadar küçük yapılar gibi görünseler de 
hem dil hem de muhteva bakımından taşıdıkları birikim ve zenginlikleriyle birer edebî eser hüviyetindedirler. Ayrıca; bu tabirler, bir milletin tecrübelerini âdeta bir öz hâlinde ihtiva eden kültür mirasları olduğu gibi aynı zamanda kelimelerin anlam inceliklerini de bünyelerinde barındıran dil zenginlikleridir. Taşıdıkları anlamlar ile kültür aktarımının mühim bir parçası olan bu tabirler, akılda kolay kalmaları sayesinde dil öğretiminde özellikle de kelimelerin anlamlarının kavratılmasında kullanılabilecektir.

Zamanla bazı yeni kelimeler türediği gibi bazı kelimeler de unutulabilir; ancak dilden dile dolaşan ve hemen hemen her edebî eserde karşımıza çıkan atasözleri ve deyimlerin muhafazası, bu unutulmayı en aza indirmemizi sağlayacaktır. Ayrıca, bazı kelimelerin anlamları unutulsa dahi atasözleri ve deyimlerin yukarıda zikredilen hususiyetlerinden dolayı eğer söz konusu kelime bir atasözü veya deyimde yaşıyorsa zamanla o kelimenin anlamı da hatırlanabilecek ve kelime geri kazanılabilecektir. Zikredilen bu hususlara bir örnek, günümüzde 'devir değişti, eski tutumların değeri kalmadı (TDK: 2011, 817a)' manasında kullanılan "Eski çamlar bardak oldu." ibaresinin 'çamdan yapılan su testisi (TDK: 1965,

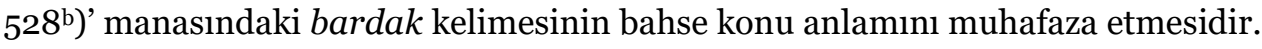

Atasözleri ve deyimler, genellikle mecazlı yapıları itibariyle kelimelerin anlam hudutlarını genişleten ve bu şekilde dili canlı tutan yapılardır. Atasözleri ve deyimler; taşıdıkları bu anlam zenginlikleri ile özellikle kelimelerin öğretilmesinde, gerçek ve mecaz anlamların kavratılmasında oldukça önemli bir kolaylık sağlayacaktadır.

Ayrıca; hem cemiyet hem de fert için söylenmiş bu sözlerin, ifade ettikleri anlamlar bakımından da önemi büyüktür; zira atasözleri ve deyimler, lisanından sâdır olduğu bir milletin efkârına delalet eder (Şināsìi: 1302, 4). Evet; atasözleri ve deyimler, taşıdıkları birikim ile hem ait oldukları milletin mazisini aksettiren hem de anlamları itibariyle o millete yol gösteren yapılardır. Bu yapıların her biri, onlarca yılda binlerce zihinden süzülerek ait oldukları milletin mazisinin mührünü üzerinde taşıyan bir öz hâline gelmiş ve küçücük yapılarıyla millî hafızanın bir ürünü olarak maziden ana, andan da atiye uzanan bir şuur taşıyıcısı olmuştur. Öyle ki bu hikmetli sözler, bazen koca bir ömürde bile elde edilemeyecek bazen de bir ömrün bitmesine sebep olacak bir tecrübeyi birkaç kelimenin sırtında taşımaktadır.

Yukarıda da zikredildiği üzere atasözleri ve deyimler, hem dil hem de muhteva bakımından taşıdıkları birikim ve zenginlikleriyle birer edebî eser hüviyetindedir ve her edebî eser gibi her bir atasözü ve deyim de yukarıda dile getirilen hususiyetleri ancak okunduğu veya söylendiği sürece yerine getirebilir. Bu sebeple, hem geçmişi doğru anlamak ve o birikimden faydalanmak hem de bu yapıları gelecek kuşaklara aktarabilmek ve özellikle de kelime öğretiminde kullanabilmek için atasözlerinin ve deyimlerin tespit edilmesine, unutulmamasına ve kullanımlarının daha da yaygınlaşmasına yönelik çalışmaların yapılması gerekmektedir.

\section{Atalar Sözü Mecmuası}

Osmanlı döneminde atasözlerinin ve deyimlerin tespitinin önemi hissedilmiş ve bugün birbirinden farklı iki unsur olarak ele alınan atasözlerinin³ ve deyimlerin4, genellikle "darbımesel5" ve "atalar sözü6"

3 TDK: TS: atasözü: Uzun deneme ve gözlemlere dayanılarak söylenmiş ve halka mal olmuş, öğüt verici nitelikte söz, deme, mesel, sav, darbımesel.: $180^{\mathrm{b}}$.

4 TDK: TS: deyim: Genellikle gerçek anlamından az çok ayrı, kendi özgü bir anlam taşıyan kalıplaşmış söz öbeği, tabir.: $651^{\mathrm{a}}$.

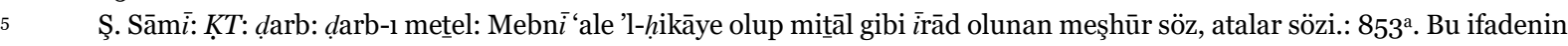
çokluğu olan "durûb-ı emsâl" de müstameldir. Ş. Sāmī: ḲT: ḍurūb: ḍurūb-1 emtāl: 853

$6 \quad$ bk. Ş. Sāmīi: KTT: darb: darb-1 metel: $853^{\mathrm{a}}$. 
adları ile ve herhangi bir ayrıma gidilmeden karışık olarak ele alındı̆̆ $1^{7}$ birçok atasözü ve deyim derlemesi kaleme alınmıştır.

Atasözleri ve deyimler konusunda hem cemiyetimiz hem de her bir ferdimiz için bugün yapılması gereken en önemli çalışmalardan biri, bu alanda geçmişte yazılmış eserleri günümüze kazandırmak olacaktır. Aslında Osmanlı döneminde yazılmış eserlerden -Şinâsînnin Durûb-ı Emsâl-i Osmâniyye'si, Vâcid'in Durûb-ı Emsâl'i, Tekezâde'ye ait Durûb-ı Emsâl-i Türkiyye yâhûd Atalar Sözü ve derleyeni belli olmayan Kitâb-ı Atalar başta olmak üzere- pek çoğu birçok çalışmada kaynak olarak zikredilmiş ve bu eserlerden bir kısmı üzerine müstakil çalışmalar da yapılmıştır. Bizim araştırmamıza konu olan Çelebioğlu Abdülhalim Hakkı'nın Atalar Sözü Mecmuası adlı eserinin ise bir tanıtma yazısına ${ }^{8}$ konu olmasına ve bazı eserlerin kaynakçalarında9 kaydedilmiş olmasına rağmen ne yazık ki bu ilgiye tam anlamiyla mazhar olduğu söylenemez.

Eserin müellifi olan Çelebioğlu Abdülhalim Hakkı'nın doğum ve ölüm tarihi tespit edilememiş olsa da en azından 1338 Temmuz 15'e [=1922 Temmuz $\left.{ }^{15}\right]^{10}$ kadar yaşadığı bilinmektedir ${ }^{11}$. Kırımlı olan ${ }^{12}$ Abdülhalim Hakkı, Osmanlı Devleti Adliye Nezaretinin yayın organı olarak yayımlanan ve birbirinin devamı olan Cerîde-yi Mehâkim¹3 ve Cerîde-yi Mehâkim-i Adliyye ${ }^{14}$ dergilerinin başkâtipliğini ve muhasebe memurluğunu ${ }^{15}$ yapmıştır.

Bu hususla ilgili bk. Aksoy, Ö. A.: Atasözleri ve Deyimler Sözlüğ̈̈ - 1 Atasözleri Sözlüğü: Eleştirmeler: 53-10o. s.

Ahmet Halil: "Kitabiyat - Millî Kanunu Kadimi Felsefî Cönkü”, Halk Bilgisi Haberleri: 1 Şubat 193o, Yıl: 1, Sayı: 4, 12a15b. s.

Bahse konu olan eserler şunlardır: Adnan Cahit: "Eski Türk Atasözleri”, Edebiyat: Ağustos 1934, 1. Yll, 2. Sayı, 30-31. s. İZBuDAK, Velet: Atalar Sözü: İstanbul 1936, Devlet Basımevi. ÜLKÜTAȘIR, M. Şakir: "Cumhuriyet Devrinde Folklor Hareketlerine Toplu Bir Bakış”, Türk Dili - Belleten: Ankara 1945, Seri: III, Sayı: 4-5, 413-444. s. ÜLkÜTAŞIR, M. Şakir: Cumhuriyetle Birlikte Türkiye'de Folklor ve Etnografya Çalışmaları: Ankara 1973, Başbakanlık Kültür Müsteşarlığ Cumhuriyetin 50. Ylldönümü Yayınları: 1. ÖzTELLI, Cahit: "Kitaplar - Türk Atasözleri (Tenkit)”, Türk Dili: 1 Ekim 1952, Sayı: 13, 44a-50a. s. Öztelli, Cahit: “Atasözleri Derlemeleri ve Kaynakçaları Üzerine”, Sivas Folkloru: Mayıs 1976, Sayı: 40, 3a-5b. s. PŁASKOWICKA-RYMkiewicz, Stanisława: "Etat des recherches concernant la parémiographie et la parémiologie turques", Rocznik Orientalistyczny: Warszawa 1965, XXVIII-2, 59-74. s. Aksoy, Ömer Asım: Atasözleri ve Deyimler: Ankara 1965, Türk Dil Kurumu Yayınları: 238. Aksoy, Ömer Asım: Atasözleri ve Deyimler Sözlüğ̈̈ - 3 Dizin ve Kaynakça: Ankara 1971, Türk Dil Kurumu Yayınları: 325/3. Oy, Aydın: Tarih Boyunca Türk Atasözleri: İstanbul 1972, Türkiye İș Bankası Kültür Yayınları. Or, Aydın: "Atasözleri Kaynakçaları Üzerine”, Sivas Folkloru: Ekim 1976, Sayı: 45, 3a-7b. s. SoykuT, İ. Hilmi: Türk Atalar Sözü Hazinesi: İstanbul 1974, Ülker Yayınları. AlANGu, Tahir: Türkiye Folkloru Elkitabr: İstanbul 1983, Adam Yayınları. BARTHA, Júlia: “Keleti utalások szóláshagyományainkban”, Jászkunság: 2001 JúliusDecember, VII/3-4, 105-109. s. BARTHA, Júlia: A Kunság népi kultúrájának keleti elemei: Debrecen 2002, Studia Folkloristika et Ethnographica 44. ERŞAHIN, İbrahim: Halk Kültürü ve Edebiyatı Sözlüğü: İstanbul 2005, Ötüken Neşriyat. AlbaYRAK, Nurettin: Türkiye Türkçesinde Atasözleri: İstanbul 2009, Kapı Yayınları: 184.

10 Bu tarih, yazmanın yaprakları arasında yer alan 1337 Sa'bānu 'l-Mu'azzam 6 [=1921 Nisan 15] tarihli takvim yaprağının arkasına müellif tarafından kaydedilmiş olan not içerisinde zikredilmektedir. Ayrıca, yazmanın sayfaları arasında aynı takvime ait pek çok takvim yaprağı daha mevcut olup bu yaprakların günümüze en yakın tarihlisi 1921 Eylül 1'e aittir. Eserin sayfaları arasında 1923 Mayıs 19 tarihli bir takvim yaprağı da bulunmakla birlikte bu takvim yaprağı diğerlerinden farklı olduğu gibi üzerinde de herhangi bir not veya imza/paraf da bulunmamaktadır. Eser içerisinde müellife ait olmayan kâğıtlar da mevcut olduğundan bu takvim yaprağındaki tarih esas alınmamıştır.

$11 \quad$ Eser içerisindeki bir kâğıtta “Abdülhalim Hakkı’nın emekli iken Kızıltoprak’ta Çiftehavuzlar'da merhum Kemal Paşa hanesinde mukim olduğu" kayıtlıdır. Ayrıca, "Üsküdar'da oturup sabah akşam İstanbul'u seyr ü temaşa eylemek pek hoştur, derler." ifadesinin altına düștüğ̈̈ "Mücerreptir, abd-i âcizce de [Abdülhalim Hakkı]" notundan müellifin bir dönem Üsküdar’da da ikamet ettiği anlaşlabilir. bk. Atalar Sözi Mecmū'ası: 216/30.

12 bk. Atalar Sözi Mecmū'ası: Cāmi', Mürettib ve Muharririnin İfāde-yi Mahṣūṣası ve İżāhātı: I. s.

13 Osmanlı Devleti [1300-1922] Adliye Nezaretinin yayın organı olan dergi, ilk defa Mayıs(?) 1873 tarihinde haftalık olarak yayımlanmaya başlanmıştır. Geniş bilgi için bk. YAvUz, H.: "Cerîde-yi Mehâkim", DíA: 7, 408c-409b. s.

Cerîde-yi Mehâkim, 1319 Cemaziyelahir 29 (1901 Ekim 13) tarihinden itibaren Cerîde-yi Mehâkim-i Adliyye adıyla neşredilmiştir. 'Adliyye Nezāāeti: Ceride-yi Mehākim-i 'Adliyye: İstanbul 29 Cemādiye 'l-āhnir 1319, Numero: 1, Maṭba'ayı 'Otmāniyye. Yavuz, H.: "Cerîde-yi Mehâkim”, DİA: 7, 408c-409's. s.

15 Müellifin Cerîde-yi Mehâkim dergisinin başkatibi olduğu, Necip Asım'a [YAZIKsız] [1861-1935] gönderdiği ve 1898 Ekim 1'de

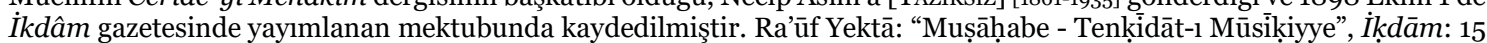

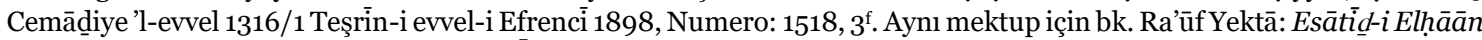
- 'Aded 2: Hvāce 'Abdü 'l-Kădir-i Merāğ í: 99. s. Müellifin Necip Asım'a gönderdiği mektubunda tarih bulunmamakla birlikte mektubun 1898 Eylül 21 ila 1898 Eylül 30 tarihleri arasında yazıldığı açıktır; zira müellif, mektubunun başında Necip Asım’ın 1898 Eylül 21 tarihli İkdâm gazetesinde yayımlanan yazısına atıfta bulunmuştur. Necỉb ‘Āṣım: "Mușāḥabe 
Abdülhalim Hakkı, Atalar Sözü Mecmuası'nın mukaddimesinde atasözleri ile ilgili çalışmasının yanı sıra başka "millî eserler" de kaleme aldığını16 ve bunların "Türk tarihi"17 ve "Türk takvimi"18 ile ilgili olduğunu belirtmektedir. Şecere-yi Tevārīh, Çag்-nāme-yi Sāl-i Türkān ve Çagan-ı Türkānn ${ }^{19}$ adlı bu üç eser tespit edilememiş olmakla birlikte Atalar Sözü Mecmuası'nın sayfalarının arasında yer alan takvim yaprakları üzerine kaydedilmiş "hübûtî takvim²0" ile ilgili müellife ait notlar, bahse konu "Türk takvimi”ne dair ipucu vermektedir ${ }^{21}$.

Ayrıca, Abdülhalim Hakkı'nın bir de yayımlanmış mektubu mevcuttur. Müellifin Necip Asım’a [YAZIKSIZ] [1861-1935] yazdığı, Abdülkâdir-i Merâğ̂̀’nin [ö. 838/1435] hayatı ile ilgili bu mektup, Rauf Yekta Bey [1875-1935] tarafindan önce 1898 Ekim 1'de İkdâm gazetesinde yayımlanan "Tenkîdât-ı Mûsîkiyye" isimli yazının sonunda²2, sonra da Esâtîz-i Elhân isimli eserde 23 neşredilmiştir.

Atalar Sözü Mecmuası, Türk Dil Kurumu Kütüphanesine Atalar Sözü adı ve Etüt/104-1 ile Etüt/104-2 numaralarıyla kayıtlı iki ciltten müteşekkil ve Arap harfleri temelli Osmanlı elifbası ile kaleme alınmış bir yazmadır. Rika hattıyla yazılmış olan eserin birinci cildi $32 \mathrm{~cm}$ x $21 \mathrm{~cm}$ ebadında, ikinci cildi ise 33 cm x $21 \mathrm{~cm}$ ebadındadır. Yazma, toplam 1994 sayfa olup birinci cilt 883 (III+XXII+796+62) sayfa, ikinci cilt ise $1111(1080+31)$ sayfadır. ${ }^{24}$

Atalar Sözü Mecmuası'nın yazılması, 1314 Ağustos 10’dan [=1898 Ağustos 22] başlayarak en azından 1339 Rebiyülevvel 1’e [=1920 Kasım 12 $]^{25}$ kadar yirmi yılı aşkın bir süre ile devam etmiştir.

- Tedkire-yi Mūsīkī-şināsān Hakkıında Bir Mütāla‘a”, İkdām: 5 Cemādiye 'l-evvel 1316/21 Eylül-i Efrencī 1898, Numero: 1508, $3^{\mathrm{c}}-3^{\mathrm{d}}$. Atalar Sözü Mecmuası'nda ise müellifin Cerîde-yi Mehâkim-i Adliyye'nin başkâtibi (bir yerde de ilgili derginin başkâtibi ve muhasebe memuru) olduğu kaydedilmiştir. bk. Atalar Sözi Mecmū'ası: Cāmi‘, Mürettib ve

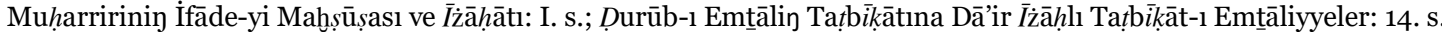

16 bk. Atalar Sözi Mecmū'ası: İç kapak.

17 bk. Atalar Sözi Mecmū'ası: 451. s. Müellif, bu sayfada Türk tarihi ile ilgili eserinde "hanların ve hükümdarların șecereleri ile ilgili tafsilatlı malumat” verileceğini kaydetmiştir.

18 bk. Atalar Sözi Mecmū‘ası: Cāmi‘, Mürettib ve Muharririnin İ́āde-yi Mahsūsasası ve İżāhātt: I. s.

19 Bu eserlerin isimleri; mukaddimede iki farklı yerde, 1339 Rebiyülevvel 1 [=1920 Kasım 12] tarihli takvim yaprağının arkasında (Şecere-yi Tevārīh, Çā g-nāme-yi Sāl-i Türkān), 1338 Haziran 10 [=1921 Haziran 10] tarihli takvim yaprağı üzerinde (Ça gan Çaǵg-nāme-yi Türkān) ve yazmanın 451. sayfasında (Şecere-yi Sāl-i Türkān) zikredilmektedir. bk. Atalar Sözi Mecmū'ası: Durūb-ı Emțāl-i Türkānın En Ehemm ve Elzem Olan ve Ḍarb u İrādında Ri‘āyeti Vücūb Derecede Mühimm Bulunan Ba‘ż

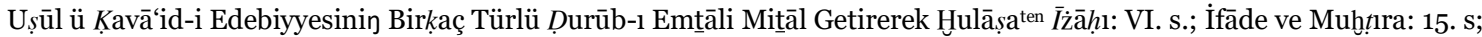
451. s; 580-581. s; 1141-1142. s.

$20 \quad$ Arapça bir kelime olan hubūt' akabinde ikamet gelen nüzul' manasındadır. el-AskERî, Ebû Hilâl: el-Furûqfi 'l-Luğa / Arab Dilinnde ve Kur'an'da FARKLAR SözLƯ̈̆̈U: Hübût ile nüzûl arasındaki fark: 445. Bu takvim, Hz. Âdem'in yeryüzüne indirilişini başlangıç olarak kabul etmektedir ve müellifin kaydettiği hesaplamalara göre miladî 1917 yll, hübûtî takvime göre 7511'e karşllk gelmektedir.

21 Bu hususla ilgili yazmanın yaprakları arasında yer alan 1338 Haziran 10 [=1921 Haziran 10] tarihli takvim yaprağ üzerindeki notlarla 1339 Rebiyülevvel 1 [=1920 Kasım 12] tarihli takvim yaprağının arkasındaki notlara bakılabilir. Ayrıca, ilgili takvim ile ilgili müellif tarafindan kaydedilmiş hesaplamalar da yazmanın yaprakları arasına konulmuş bir kâğı üzerinde yer almaktadır.

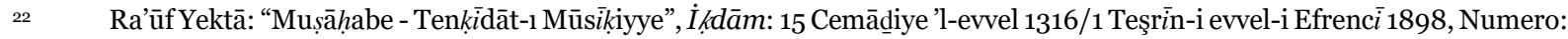
$1518,3^{\mathrm{f}}$.

Ra'ưf Yektā: Esātīd-i Elhān - 'Aded 2: Hvāce 'Abdü 'l-Kădir-i Merāăği: 99. s.

24 Eserin şeklî özellikleri ile ilgili geniş bilgi için bk. AlEMDAR, E.: “Çelebioğlu Abdülhalim Hakkı’nın Atalar Sözü Mecmuası", Dîvânu Lugâti't-Turk'ten Senglah'a Türkçe - Doğumunun 60. Yllında Mustafa S. Kaçalin Armağanı: 91. s.

25 Her ne kadar yazmanın başında "Tārīh-i tertỉb ve tahrīir ibtidāsı 1314'den [=1898] 1324 [=1908] sene-yi māliyyesine kadar devām ètmişü̈r.” kaydı düsülmüsse de 1324’ten [=1908] sonra da müellif tarafından yazmaya eklemeler yapıldığı aşikârdır. Eserin yazım tarihi ile ilgili geniş bilgi için bk. Alemdar, E.: "Çelebioğlu Abdülhalim Hakkı'nın Atalar Sözü Mecmuası", Dîvânu Lugâti’t-Turk'ten Senglah'a Türkçe - Doğumunun 6o. Yılında Mustafa S. Kaçalin Armağanı: 86. s. 
Çalışmamıza konu olan esere ${ }^{26}$ müellif tarafından birkaç isim verilmiş ve bu isimler yazmada çoğunlukla bir arada kullanılmıştır ${ }^{27}$. Müellifin, eseri için kullandığı isimler; yazmada kullanıldıkları sıraya göre şunlardır:

- $\quad$ Vesaik-i Medeniyye vü İlmiyyeden Madûd Olunan Örf ü Âdât ve Millî Kanun-ı Kadim-i Felsefi Cöngü / Savlar, Sinavlar ve Kaide-yi Kadimeler Mecmuası

- $\quad$ Sav u Sinav-ı Türkân Cöngü

- Atalar Sözü Mecmuası

- $\quad$ Durûb-ı Emsâl-i Osmanî / Durûb-ı Emsâl-i Türkî Mecmuası

- $\quad$ Iyi Sözler Cöngü / Öğüt ve İyi Nasihat Mecmuası

- $\quad$ Eski Zamanin Savlar ve Sinavlar-Tecrübeler-Cöngü

Abdülhalim Hakkı, Atalar Sözü Mecmuası'nın mukaddimesinde "millet namı altında yaşayan ve yaşamak isteyen bir kavm"in sahip olması gereken başlıca eserleri "birincisi, millî lügat ve gramer kitapları; ikincisi, millî tarih kitapları; üçüncüsü, millî atasözleri vesaireye dair kitaplar²" olarak belirtmiş, bu eserlerin yazılmasını millî bir vazife olarak gördüğünü ve bu eserlerin elinden gelebileceğine inandığı kısmı olan darbımeselleri kudreti yettiği miktarda toplayarak vazifesini yerine getirmeye çalıştığını ifade etmiştir. Mukaddimede, bu eserin ne maksatla ve nasıl yazıldığı anlatıldığı gibi müellifin atasözlerinin ehemmiyeti ve kullanılmasındaki usuller hakkındaki görüşleri de aktarılmıştır. Eserin asıl metin kısmı ise atasözü, deyim, vecize, mısra, beyit, dua, kargış gibi yapılardan oluşan madde başları, madde başlarında geçen bazı kelimelerin açılamaları ve madde başlarının geçtiği alıntılardan oluşmaktadır. Eser; Kur'an-ı Kerim'den sözlüklere, divanlardan tarih kitaplarına hatta gazete yazılarına kadar pek çok kaynaktan yapılan çok sayıda alıntıyla da dikkat çekmektedir. Eserdeki iktibasların ait olduğu kaynaklardan bazıları şunlardır:

Alî Seydî: Resimli Kâmûs-i Osmânî; Âhî: Dîvân, Hüsn ü Dil, Husrev u Şîrîn; Ahmed Cevdet Paşa: Târîhi Cevdet; Ahmed Vefîk Paşa: Lehce-yi Osmânî; Bâkî: Dîvân; Dede Ömer Rûşenî: Âsâr-ı Aşk; Ebüzziyâ Tevfîk: Muharrir; Emrullâh Efendi: Muhîtü 'l-Maârif; Evliyâ Çelebi: Seyâhatnâme; Fıtnat Hanım: Dîvân; el-Fîrûzâbâdî (Çev.: Ahmed Asım): el-Okyânûsu 'l-Basît fí Tercemeti 'l-Kâmûsi 'l-Muhît; Fuzûlî: Beng ü Bâde, Dâstân u Leylî vü Mecnûn, Dîvân, Hadîkatu 's-Suadâ, Şikâyetnâme; Halîm Giray: Dîvân, Gülbün-i Hânân; Hıfzî: Manzûme-yi Durûb-ı Emsâl; Hurûfî Arşî: Dîvân; Husayn Vâiz-i Kâşifî (Çev.: İsmâîl Ferruh): Mevâkib'29; Hüseynî (Hüseyn-i Baykara): Dîvân; Hoca Sadeddîn Efendi: Tâcü 'tTevârîh; İbn Haldûn: Mukaddimeso; İbrâhîm Peçevî: Târîh-i Peçevî; Kâşgarlı Mahmûd: Dîvânü Lugâti

26 Eser, kaynaklarda çoğunlukla Millî Kanun-ı Kadim-i Felsefí Cöngü ismiyle ya da Atalar Sözü / Mecmuası isimleriyle kaydedilmiştir. Bu başlıklar içerisinde Atalar Sözü Mecmuası isminin yazma içerisinde daha fazla kullanılması ve müellifin üç farklı yerde özellikle eserine bu ismi verdiğini belirtmesi sebebiyle biz de eseri bu isimle kaydediyoruz. Ayrıca, eserden bahseden kaynaklardan birinde diğer kaynaklardan farklı olarak eser, Atasözleri ve Halk Tabirleri ismi ile kaydedilmiş. ÜLKüTAŞIR, M. Ş.: Cumhuriyetle Birlikte Türkiye'de Folklor ve Etnografya Çalışmaları: 19. s.

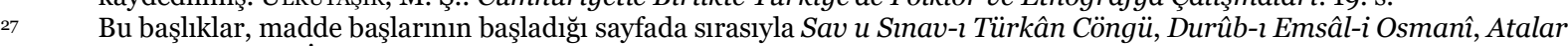
Sözü Mecmuası, İyi Sözler Cöngü, Eski Zamanın Savlar ve Stnavlar-Tecrübeler-Cöngü olarak kaydedilmiştir. bk. Atalar Sözi Mecmū‘ası: 4. s. İlgili başlıkların bazıları mukaddimenin başlangıcında ise sırasıyla Sav u Sinav-ı Türkân Cöngü, Atalar Sözü Mecmuası ve Durûb-ı Emsâl-i Osmanî olarak yer almıştır. bk. Atalar Sözi Mecmū'ası: I. s. bk. Atalar Sözi Mecmū'ası: Muḳaddime’ye 'ilāve-yi hāmiş olaraḳ ba‘ż-ı mütāla‘āt u mülāhazāt-ı muharririhi: VIII. s.

29 Asıl adı al-Mavāhibu 'l-'Aliyya olan ve Tafsìr-i ḩusaynī adıyla da bilinen bu eseri İsmā'il Ferruh [ö. 1256/184o] bazı ilave ve kısaltmalarla Mevākib adıyla Türkçeye tercüme etmiştir. BỉrişıK, A.: "Muhtasar - Tefsir”, DİA: 31, 59". KARAİSMAİLOĞLU, A.: "Hüseyin Vâiz-i Kâşifi”", $D \dot{I} A$ : 19, $17^{\mathrm{b}}$.

3o İbn Haldūn'un [732/1332-808/1406] bu eserinin asıl adı, Kitābu 'l-'Íbar va dìvānu 'l-mubtada' va 'l-ḩabar fī ayyāmi 'l-‘Arab va 'l-'Acam va 'l-Barbar va man ātarahum min davi 's-sulțāni 'l-akbar'dir. Bu eser; birinci kitabını I. cildin, ikinci kitabını II. - V. ciltlerin ve üçüncü kitabını VI. ve VII. ciltlerin meydana getirdiği dünya tarihi niteliği taşıyan bir eserdir. İbn Haldūn; eserin girişinde tarih ilminin ehemmiyetine, tarih yazımında takip edilen usullerin araştırılmasına, tarihçilerin düştükleri hatalara temas etmiş ve tarih ilminin kapsamlı bir tarifini yaparak kendi tarih anlayışını ortaya koymuştur. Müellifin "beşerî umran ilmi” adını verdiği yeni ve özgün bir ilim dalından da bahsettiği bu girişe, araştırmacılar ayrı bir 
't-Türk; Kemâlpaşazâde (İbn Kemâl): Dîvân; Mehmed Celâl: Osmânh Edebiyâtı Numûneleri; Mehmed Tevfîk'31: Mecmûa min Nevâdiri 'l-Üdebâ vü Âsâri' 'z-Zurefâ (Nevâdirü 'z-Zurefâ); Mevlânâ Celâleddîni Rûmî (Çev.: Süleymân Nahîfî): Mesnevî-yi Manevî; Muallim Nâcî: Ateşpâre, Fürûzân, Lugat-i Nâcî, Sünbüle, Şerâre; Muhibbî: Dîvân; Nâbî: Dîvân, Hayrâbâd, Hayriyye; Nâmık Kemâl: Cezmî, Sâkînâme, Tahrîb-i Harâbât; Necîb Âsım: Türk Târîhi; Nedîm: Dîvân; Nefî: Dîvân, Sihâm-ı Kazâ; Nevâyî: Garâibü 's-Sigar, Hayretü 'l-Ebrâr; Solakzâde Mehmed Hemdemî Çelebi: Solakzâde Târîhi; Sûfî Allâhyâr: Sebâtu 'l-Âcizîn; Süleymân Çelebi: Vesîletü 'n-Necât; Sünbülzâde Vehbî: Dîvân, Lutfiyye-yi Vehbî, Tuhfe-yi Vehbî; Şemseddîn Sâmî: Kâmûs-i Türkî, Kâmûsü 'l-Alâm; Şeyh Gâlib: Dîvân, Hüsn ü Aşk; Şeyh Süleymân Efendi-yi Buhârî: Lugat-i Çağatay ve Türkî-yi Osmânî; Şeyhülislâm Yahyâ: Dîvân; Şinâsî - Ebüzziyâ: Durûb-ı Emsâl-i Osmâniye; Lousis Víardot (Çev.: Ziya Paşa): Endülüs Târîhi; Yahyâ Nazîm: Dîvân I-V; Yûnus Emre: Dîvân; Zemahşerî: Nevâbigu 'l Kelim; Ziya Gökalp: İslâmiyet ve Asrî Medeniyet; Ziyâ Paşa: Eşấr-ı Ziyâ, Harâbât, Terkîb Bend, Tercî Bend.

Yalnızca bir atasözü ve deyim derlemesi olmayıp pek çok kelimenin farklı biçimlerinin kaydedildiği ve bazı açıklamalar, hikâyeler, anekdotlar, mütalaalar vb. yapılar da ihtiva eden Atalar Sözü Mecmuası'nda günümüz Türkiye Türkçesinde kullanılmayan veya mevcut biçiminden kısmen farklı olarak kullanılan atasözleri ve deyimler de mevcuttur. Ayrıca, her sayfasında ortalama otuz satır bulunan toplam 1994 (birinci cilt: III+XXII+796+62, ikinci cilt: $1080+31$ ) sayfadan müteşekkil olan, hacmi geniş ve muhtevası zengin bu eser içerisinde yalnızca Osmanlı Türkçesine ait maddeler ve alıntılar değil; ekserisi -müellifin ifadesiyle- "Osmanlı Türkçesine tahvil edilmiş" olmakla birlikte Çağatayca, Kipçakça ve Tatarca gibi öbür Türk lehçelerine ait maddeler ve alıntılar da mevcuttur.

Osmanlı Türkçesine veya Çağatayca, Kıpçakça ve Tatarca gibi öbür Türk lehçelerine ait olup atasözleri ve deyimlerle ilgili günümüz Türkiye Türkçesindeki hâlihazırdaki kaynaklarda bulunmayıp Atalar Sözü Mecmuası'nda yer alan ve mevcut kaynaklardakilerden farklı biçimleriyle kayda geçen maddelerden bazıları şunlardır:

- Apaḳ çapaḳ oldılar, birbirisin buldılar. ${ }^{32}\left[{ }_{[10 / 23]}\right.$ (Çağatayca)

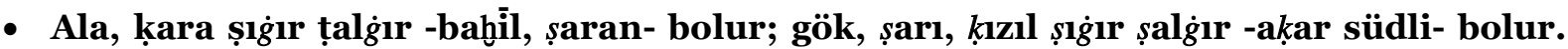
[118/ek/21] (Kıpçakça)

- Aşın verme, kaşın ver. [64/17, 64/18]

Madde başının yanına müellif tarafından "Kaş’tan murat güler yüzdür." diye not düşülmüş. Bu açıllamaya uygun olarak öbür Türk lehçelerinde kullanılan (ÜLKÜSAL: 1970, 21) ilgili atasözü,

değer vermişlerdir. İbn Haldūn'un Mukaddime olarak bilinen meşhur eseri, aslında bu girişin de içinde yer aldığı Kitābu 'l-'̇̉bar'in altı ana bölüme ayrılmış olan birinci kitabıdır. Daha geniş bilgi için bk. ULUDAĞ, S.: "İbn Haldûn", DİA: 19, 538 $8^{\text {b- }}$ $543^{\mathrm{c}}$. s.

$31 \quad$ Bu eser, bazı kaynaklarda Çaylak Mehmed Tevfik'e [1843-1893] ait gösterildiği gibi ona ait olmadığı da savunulmaktadır. Geniş bilgi için bk. AKÜN, Ö. F.: “Çaylak Tevfik”, Di்A: 8, 244. Eser, Ebü '̇̇-Żiyā Mehmed Tevfīk'e [1849 - 1913] ait olabilir; zira bir mahpus ve sürgünün kendi adıyla yazı yazması yasak olduğundan Rodos’ta sürgünde olduğu dönemden sonraki (1875 Kasım vd.) yazılarında büyük oğlu Ziya'ya nispetle Ebü '̇̇-Żya takma adını kullanmaya başlayan Ebü ’ż-Żiyā Mehmed Tevfīk, 1875 Kasım'dan önceki yazılarında Meḥmed Tevfík imzasını kullanmıștır. bk. EвÜZziYA, Z.: "Ebüzziyâ Mehmed Tevfik”, DIA : 10, 375 . Ayrıca, eserin Toronto Üniversitesi John P. Robarts Araştırma Kütüphanesine AAC-8856 numarası ile kayıtlı bulunan nüshasında her cildin başında mütalaa tarihi var: I. 22 Şevvāl 287 [15 Ocak 1871]; II, 15 Muharrem 288 [6 Nisan 1871]; III. 27 Cā[Cemādiye 'l-evvel] 289 [2 Ağustos 1872]. Eser içerisinde on beş sayfası aynıyla yer alan A h̆med Vefikk Paşa'nın Türki Durūb-ı Emțāl'i 1871'de yayımlanmış. Bu sebeplerle, Mecmū'a min Nevādiri 'l-Üdebā vü $\bar{A} \underline{t} \bar{a} r i$ ' $z$-Zurefä'nın basım tarihi 1871 olmalı.

32 Şeyh Süleymān: LÇvT'O: apak çapak: Șul h u șalāh, tecdīd-i münāsebet, ke 'l-evvel, barışık. Mitaāl: Apak çapak oldılar, birbirisin buldılar.: $3^{\text {a }}$. 
günümüz Türkiye Türkçesinde ise “Aşını verme, kaşı̆̆ını ver.” biçimiyle müstameldir (ALBAYRAK: $\left.2009,180^{b}\right)$.

- Atayda 33 at da yo $k$ it de yo $k$, ur Teñri'm $k \operatorname{kgyani}^{34}$ (țavşanı). [11/17] (Nogayca)

- Arpa, körpe35 (kepek) aş imiş; altun, kümüss țaş imiş. [49/14] (Tatarca)

- Anca beraber, manca beraber... [137/20]

Günümüz Türkiye Türkçesinde: “Anca beraber, kanca beraber.” (AKsoY: 1971, 472)

\section{- Başını terkiye koymak... [192/05]}

‘Ölümü göze almak’ manasında...

\section{- Ekmek ${ }^{36}$, kesildikten sonra bir daha birikmez37 (yapışmaz). [166/30]}

Madde başının yanına müellif tarafından "Kız, kocaya gittikten sonra anaya babaya bir daha katılmaz.' demek...” diye not düşülmüş.

- Elini diline öptürmek... [304/o6, 304/o7]

- Elinin sütünü emmek... [303/26, 304/o1, 314/22]

'Bir kimseden faydalanmak' manasında...38

\section{- Eski çamlar bardak oldu. Eski camlar bardak oldu. Eski bardaklar cam oldu.}

- $\quad$ O çamlar bardak oldu. ${ }_{[421 / 13]}$ Eski, bildigiñ çamlar bardak oldı. [202/40] Evvelki çamlar bardak oldl. [398/31]

Buradaki bardak kelimesi 'çamdan yapılmış su testisi (TDK: 1965, 528)' manasında olup bahse konu ifade 'devir değişti, eski tutumların değeri kalmadı (TDK: 2011, 817a)' anlamındadır.

- $\quad$ Eski camlar bardak oldı. 202/38 Evvelki camlar şimdi bardak oldı. 403/11 O camlar çokdan bardak oldı. 421/04 Eski camlar bardak oldu; bardaklar badeye, badeler saki-yi gülçehre eliyle sarhoşlara yardak oldu. 203/10

- $\quad$ Eski bardaklar cam oldu. [202/38]

33 Türk dillerinde 'baba' veya 'dede' manalarında müstamel olan bu kelime, aslen selenme biçimidir. Lì, Y-S.: Türk Dillerinde

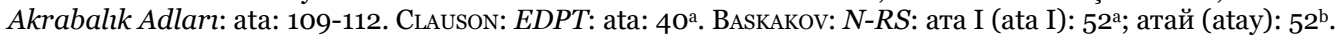

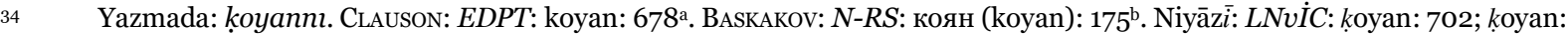
Tavşan.: 966. TOPARLI-VURAL-KARAATLI: KTS: koyan: Tavşan.: $155^{\text {b }}$. ÖNER: K-TTS: kuyan: $309^{\text {b }}$.

35 Müellif, körpe kelimesinin kullanıldığı bazı madde başlarında bu kelimenin ilgili madde başındaki manasını şu şekilde belirtmiş: 'buğday kırması, bulgur' (bk. 24/17), 'bulgur' (bk. 26/ek2/o5, 43/ek/o2), 'dövülmüş arpa ve buğday' (bk. 44/ek2/o8), 'kepek' (bk. 49/14, 15). 'Abdü 'l-Kayyūm ‘Abdü 'n-Nāṣır oğlı: Lehce-yi Tatarì: körpe: Unnı èlegeç èlek üstinde

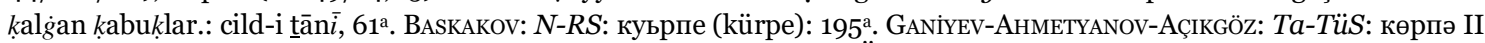
[körpe]: Un elendiğinde elekte kalan un ve kepek kalıntısı.: 194 . ÖNER: K-TTS: körpe (II): Kepek, kalbur kalıntısı, çalkantı.: 229a. ÖZZ̧AHIN: BTS: körpe (1): Hububat, yarma.: 299ª ǗLKÜSAL, M.: Dobruca'daki Kırmm Türklerinde Atasözleri ve Deyimler: kŭrpe: Bulgur.: 240 .

36 Yazmada: etmek. CLAuSON: EDPT: etmek/ötmek: 60ª ekmek: 108 ${ }^{\text {b }}$ Muhammad Mahdī Xān: Sanglax: etmek: 30v25;

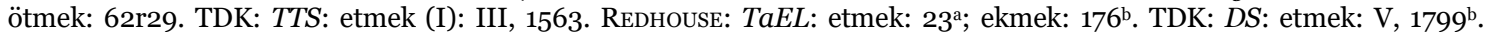
KaÇALin, M. S.: Dedem Korkut’un Kazan Bey Oğuz-nâmesi: 140. KaçALìn, M. S.: “Ekmek”, Yemek ve Kültür: 4, 61-70.

37 CLAUSON: EDPT: birik-: 363a . TDK: TTS: birikmek: Birleşmek, bir araya gelmek, ittihat etmek.: I, 594.

${ }_{38}$ Müellif, "elinin sütünü emmek" ifadesini 'emeği geçmek' seklinde açıklamıstır. İlgili açıklama için bk. Atalar Sözi Mecmū'ast: 314/22. Bu ifadenin '(bir kimseden) faydalanmak' manasında olduğu, 'emeği geçmek' anlamının ise faydası dokunan kişi zaviyesinden bir anlamlandırma olduğu anlaşılmaktadır. 


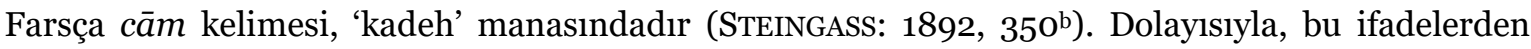
"Eski bardaklar cām oldı.” 'devir değişti, değersiz şeyler kıymetlendi, değersiz şeylere kıymet verilir oldu' şeklinde, "Eski cāmlar bardak oldı.” ise 'devir değişti, kıymetli şeyler değersizleşti, kıymetli şeylere değer verilmez oldu’ şeklinde anlaşlabilir.

- Ettiği, canına kâr kalmak... [493/25]

- Kaş yakayım derken göz çıkarmak... [31/15, 104/04]

Günümüz Türkiye Türkçesinde: “Kaş yapayım derken göz çıkarmak.” (AKSOY: 1971, 772)

- Özünki, özüne özek ${ }^{39}$ sokar. [444/32, 445/10, 445/20]

Bu ifadenin 'Zararın en büyüğü, en yakınından gelir.' manasında olduğu anlaşlmaktadır; zira yazmada bu madde başının benzer bir biçimi olarak "Öz akraban, özüne özek sokar. [442/37]" şeklinde bir madde başı daha bulunmaktadır.

- Uzaktaki kişneşir, yakındaki dişleşir. [244/16, 245/26, 442/o1, 442/33]

Madde başının yanına müellif tarafından “Kötü dost, kötü akrabadan kinayedir.” diye not düşülmüş. Bahse konu atasözü, Altay Türkçesinde müstameldir.

Ayrıca, eserde Arapça cümle yapısına sahip olmakla birlikte içinde Türkçe kelimeler de bulunan maddeler de mevcuttur. Bunlardan bazıları şunlardır:

- El-akdemü fe 'l-akdem [=Önce olan önceliklidir.], nefis her şeyden akdem. [296/ek/17]

- El-hedâyâ tüşterek, velev kâne beş börek. [309/26]

[=Beş börek dahi olsa hediyeler paylaşılır.]

- El-İslâmu bi 'l-îmân, velev kâne biñ yaman. [296/ek/o2]

[=Çok kötü de olsa Müslümanlık imanladır.]

- El-İslâmu ke 'l-kardaş, velev kâne Kizllbaş. [296/ek/o1, 309/21]

[=Kızılbaş dahi olsa Müslümanlar kardeş gibidir.]

- El-vekîli ke 'l-asîl, velev kâne Kör Vasil. [304/12, 309/31, 313/14]

[=Kör Vasil dahi olsa vekil, asil gibidir.]

- Eş-şerîki ke 'l-kardaş, velev kâne Kuzılbaş. [160/12, 296/13, 309/23, 313/15]

[=Kızılbaş dahi olsa ortak, kardeş gibidir.]

39 TDK: DS: özek (III): Arabalarda ön ve arka dingili birbirine bağlayan uzun ağaç direk.: IX, 3369 ; özek (II): İki tekerleği birbirine bağlayan ağaç.: XII, 4630 ${ }^{\mathrm{b}}$. TDK: TS: özek ağacı: 1866 . CLAUSON: EDPT: özek: $285^{\mathrm{a}}$. 


\section{Sonuç}

Yukarıda zikredilen hususiyetlerinden de anlaşıldığı üzere, şümullü bir eser olan Çelebioğlu Abdülhalim Hakkı'nın Atalar Sözü Mecmuası'nın tamamının çalışılarak istifadeye sunulması ile, atasözlerini ve deyimleri tespit etmek; bunların daha önce kayda geçmemiş olanlarını kayda almak, unutulmuş olanlarını yeniden iktisap etmek, unutulmak üzere olanlarını koruyabilmek; atasözlerini ve deyimleri kaynak eserlerde kullanıldıkları biçimleriyle tespit edebilmek; Osmanlı Türkçesine ait olanların yanı sıra Çağatayca, Kıpçakça ve Tatarca gibi Türkçenin öbür lehçelerinden aktarılmış olan kelimeleri, atasözlerini ve deyimleri de Türkiye Türkçesine kazandırabilmek hususlarına katkıda bulunulabilecektir.

\section{Kaynakça}

ABDÜLHALIM HAKKI: Atalar Sözü: Türk Dil Kurumu Kütüphanesi, I, Etüt/104-1; II, Etüt/104-2.

'Adliyye Neẓāreti: Cerīde-yi Meḥākim-i ‘Adliyye: İstanbul 29 Cemāạdiye 'l-āhirir 1319, Numero: 1, Maṭba'ayı 'Oțmāniyye.

Adnan Cahit: "Eski Türk Atasözleri”, Edebiyat: Ağustos 1934, 1. Yıl, 2. Sayl, 30-31. s.

AḤmed VEFị̣̄ PAŞA: Lehce-yi ‘Oțmānī: Der-i Sa'ādet 1306, Maḥm̄̄d Beg Maṭba'ası.

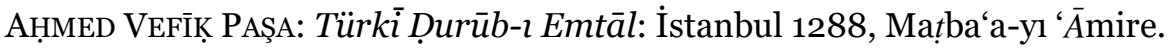

AHMET HALIL: “Kitabiyat - Millî Kanunu Kadimi Felsefi Cönkü”, Halk Bilgisi Haberleri: 1 Şubat 1930, Yll: 1, Sayı: 4, 12 ${ }^{\mathrm{a}}-15^{\mathrm{b}}$. s.

Aksoy, Ömer Asım: Atasözleri ve Deyimler Sözlüğü - 1 Atasözleri Sözlüğü: Ankara 1971, Türk Dil Kurumu Yayınları: 325.

Aksoy, Ömer Asım: Atasözleri ve Deyimler Sözlüğü - 2 Deyimler Sözlüğü: Ankara 1971, Türk Dil Kurumu Yayınları: 325/2.

Aksoy, Ömer Asım: Atasözleri ve Deyimler Sözlüğü - 3 Dizin ve Kaynakça: Ankara 1971, Türk Dil Kurumu Yayinları: 325/3.

AKsoY, Ömer Asım: Atasözleri ve Deyimler: Ankara 1965, Türk Dil Kurumu Yayınları: 238.

AKÜN, Ömer Faruk: “Çaylak Tevfik”, Türkiye Diyanet Vakf İslâm Ansiklopedisi: İstanbul 1993, Cilt: 8, $240^{\mathrm{a}}-244^{\mathrm{c}}$. s. Türkiye Diyanet Vakfı.

AlANGU, Tahir: Türkiye Folkloru Elkitabı: İstanbul 1983, Adam Yayınları.

ALBAYRAK, Nurettin: Türkiye Türkçesinde Atasözleri: İstanbul 2009, Kapı Yayınları: 184.

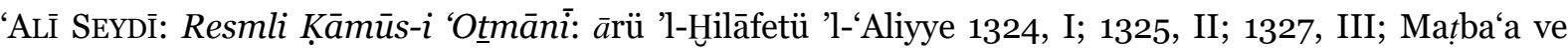
Kütüb-ḩāne-yi Cehān.

ALEMDAR, Ensar: “Çelebioğlu Abdülhalim Hakkı'nın Atalar Sözü Mecmuası”, Dîvânu Lugâti’t-Turk'ten Senglah'a Türkçe - Doğumunun 6o. Yılında Mustafa S. Kaçalin Armağanı: Yayına Hazırlayanlar: Mehmet ÖLmEZ, Tülay ÇulHA, Kübra ÖZÇETiN: İstanbul 2017, 77-112. s. Kesit Yayınları. Türk Dilleri Araştrımaları Dizisi: 66.

AlEMDAR, Ensar: Kaynaktan Eğitime Atasözleri ve Deyimler Çelebioğlu Abdülhalim Hakkı Atalar Sözü Mecmuası (1.-538. Sayfalar): İstanbul 2018, Marmara Üniversitesi Eğitim Bilimleri Enstitüsü Doktorluk Tezi.

el-ASKER̂̂, Ebû Hilâl: el-Furûqfi 'l-Luğa: Çeviren: Veysel AKDOĞAN: Arab Dili'nde ve Kur'ân'da FARKLAR SÖZLÜ̆ĞU: İstanbul 2009, İşaret Yayınları: 124.

ATAY, Hüseyin - İbrahim ATAY - Mustafa ATAY: Arapça-Türkçe Büyük Lûgat: Ankara 1964, I, 1. cüz; 1965, 2. cüz; 1966, 3. cüz; 1968, II, 1. cüz; 1969, 2. cüz.; 1970, 3. cüz; 1970, 4. cüz; 1981, III. 
BARTHA, Júlia: “Keleti utalások szóláshagyományainkban”, Jászkunság: 2001 Július-December, VII/34, 105-109. $\mathrm{s}$.

BARTHA, Júlia: A Kunság népi kultúrájának keleti elemei: Debrecen 2002, Studia Folkloristika et Ethnographica 44.

BASKAKOV, N. A.: Nogaysko-Russkiy Slovar' / Nogayša-Orıš̌a Sözlik: Moskva 1963, Gosudarstvennoye İzdatel'stvo İnostrannıh i Natsional'nı̧ Slovarey.

BASkakov, N. A.: Russko-Nogayskiy Slovar' / Rusša-Nogayša Slovar': Moskva 1956, Gosudarstvennoye İzdatel'stvo İnostrannıh i Natsional'nıb̆ Slovarey.

BíRIŞIK, Abdülhamit: "Muhtasar - Tefsir”, Türkiye Diyanet Vakfi İslâm Ansiklopedisi: İstanbul 2006, Cilt: $31,59^{\mathrm{a}}-60^{\mathrm{a}}$. s. Türkiye Diyanet Vakfi.

Clauson, Sir Gerard: An Etymological Dictionary of Pre-Thirteenth-Century Turkish: London 1972, Oxford University Press.

al-CuRCĀNō̄, as-Sayyid aş-Şarif: at-Ta'rífāt: Neşreden: Şeyh-zāde es-Seyyid Meḥmed Es'ad: İstanbul 1253.

CÜRCÂNî, Seyyid Şerif: Kitabu’t-Ta'rîfât: Tercüme eden: Ali ERKAN: Arapça-Türkçe TERIMLER SÖZLüĞÜ: İstanbul 1997, Bahar Yayınları Sözlük Serisi: 17.

Demirel, Özcan - Kasım KIroĞLu: Konu Alan Ders Kitabı İncelemesi: Ankara 2005, Pegema Yayınları.

DEvELLioĞLU, Ferit: Osmanhca-Türkçe Ansiklopedik Lûgat: Yayına Hazırlayan: Aydın Sami GüNEYÇAL: Yeniden Düzenlenmiş ve Genişletilmiş 11. Baskı, Ankara 1993, Aydın Kitabevi Yayınları Sözlük Dizisi: 1.

EвÜZziYA, Ziyad: “Ebüzziyâ Mehmed Tevfik”, Türkiye Diyanet Vakfi İslâm Ansiklopedisi: İstanbul 1994, Cilt: $10,374^{\mathrm{b}}-378^{\mathrm{b}}$. s. Türkiye Diyanet Vakfi.

Ehmetyanov, Rifkat - Rafael MöHemmetdinov - Fenüze NuRieva - Fuat Ganiev: Türkçe-Tatarca Sözlük: Aktaran: Mustafa ÖNER: Ankara 2014, Atatürk Kültür, Dil ve Tarih Yüksek Kurumu Türk Dil Kurumu Yayınları: 1119.

ERŞAHIN, İbrahim: Halk Kültürü ve Edebiyath Sözlüğü: İstanbul 2005, Ötüken Neşriyat.

al-FĪRŪZĀBĀDĪ, Macdu 'd-dīn Abū Ṭāhir Muḥammad bin Ya'ḳūb: al-Ukyānūsu 'l-Basīt fí Tarcamati 'lKāmūsi 'l-Muḥiṭ: Çeviren: CENĀNĪOǴLI Aḥmed 'Āṣım: İstanbul 1268, I'-r; 1269, II r-ḳ; 1272, III kv.

GANiYEv, Fuat - Rifkat AHMETYANOv - Halil AÇıKGÖZ: Tatarca-Türkçe Sözlük: Kazan-Moskova 1997, İnsan Yayınevi.

HÜSEYIN KÂZIM KADRi: Türk Lûgati - Türk Dillerinin İştikakı ve Edebî Lûgatleri: İstanbul 1928, I-II, Devlet Matbaasi; 1943, III-IV, T.D.K.

İZBUDAK, Velet: Atalar Sözü: İstanbul 1936, Devlet Basımevi.

KAÇALIN, Mustafa S.: Dedem Korkut'un Kazan Bey Oğuz-nâmesi: İstanbul 2006, Kitabevi: 288.

KaÇALIN, Mustafa S.: “Ekmek”, Yemek ve Kültür: İstanbul 2006 (Ocak), 4. Sayl, 61-70. s.

KARAİSMAiLOĞLU, Adnan: "Hüseyin Vâiz-i Kâşifi”, Türkiye Diyanet Vakfi İslâm Ansiklopedisi: İstanbul 1999, Cilt: 19,16c-18 a. s. Türkiye Diyanet Vakfı.

Karşılaştırmalı Türk Lehçeleri Sözlüğü (Klavuz Kitap): Ankara 1991, Kültür Bakanlı̆̆ı Yayınları / 1371. Kaynak Eserler Dizisi / 54.

[KÂŞGARLI MAHMUD]: Divanü Lûgat-it-Türk Tercümesi: Çeviren: Besim ATALAY: Ankara 1939, I; 1940, II; 1941, III; T.D.K. [Yayın sayısı 43, 46, 6o]

KÂŞGARLI MAHMUD: Dîvânü Lûgati't-Türk (Tipkıbasım/Facsimile): Ankara 1990, Kültür Bakanlı̆̆1 Yayıları/1205. Klasik Eserler Dizisi/11. 
Li, Yong-Sŏng: Türk Dillerinde Akrabalk Adları: İstanbul 1999, Simurg Türk Dilleri Araştırmaları Dizisi: 15 .

MílLî KÜTÜPHANE BAŞKANLIĞI: Türk Atasözleri ve Deyimleri I: İstanbul 2001, Millî Eğitim Bakanlığı Yayınları: 2174. Bilim ve Kültür Eserleri Dizisi: 485. Araştırma İnceleme Dizisi: 15.

MílLî KÜTÜPHANE BAŞKANLIĞI: Türk Atasözleri ve Deyimleri II: İstanbul 2001, Millî Eğitim Bakanlığ1 Yayınları: 2175. Bilim ve Kültür Eserleri Dizisi: 486. Araştırma İnceleme Dizisi: 15.

Muhammad Mahdī X̄̄N: Sanglax A Persian Guide to the Turkish Language. Facsimile Text with an Introduction and Indices by Sir Gerard ClAUSON: London 1960, Lusac and Company, "E. J. W. GIBB Memorial” Series, New Series, XX.

MuZAFARov, Refik - Nüzhet MuZAFarov: Krrm Tatar Türkçesi - Türkiye Türkçesi - Rusça Sözlük: Çeviren: Neriman SEYITYAHYA (SEYTYAGYAYEv): Ankara 2018, Atatürk Kültür, Dil ve Tarih Yüksek Kurumu Türk Dil Kurumu Yayınları: 1256. Türk Dillerinin Sözlükleri 16a: Kırım Tatarcası.

Necỉ 'Āṣım: "Muṣāhabe - Tedِkire-yi Mūsīḳi-şināsān Ḥaḳḳında Bir Müțāla'a”, İḳdām: 5 Cemāḍiye 'levvel 1316/21 Eylül-i Efrenci 1898, Numero: 1508, $3^{\mathrm{c}}-3^{\mathrm{d}}$.

NişANYAN, Sevan: Nişanyan Sözlük - Çağdaş Türkçenin Etimolojisi: İstanbul 2018, Liber Plus Yayınları: 28. Nişanyan Kitapları: 01.

NiYĀZĩ: al-Luġātu 'n-Navāìyya va 'l-İstişhādātu 'l-Cag̉atāìyya: Hazırlayan: Mustafa S. KAÇALiN: Nevâyı̂’nin Sözleri ve Çağatayca Tanıklar: Ankara 2011, Atatürk Kültür, Dil ve Tarih Yüksek Kurumu Türk Dil Kurumu Yayınları: 1027.

OY, Aydın: “Atasözleri Kaynakçaları Üzerine”, Sivas Folkloru: Ekim 1976, Sayı: 45, 3a-7b. s. SoYKUT, İ. Hilmi: Türk Atalar Sözü Hazinesi: İstanbul 1974, Ülker Yayınları.

OY, Aydın: Tarih Boyunca Türk Atasözleri: İstanbul 1972, Türkiye İş Bankası Kültür Yayınları.

ÖNER, Mustafa: Kazan - Tatar Türkçesi Sözlüğü: Ankara 2015, Atatürk Kültür, Dil ve Tarih Yüksek Kurumu Türk Dil Kurumu Yayınları: 963.

ÖZDEN, Mehtap: “Türkçe Kaynak Metinler ve Türkçe Eğitimi”, Dil ve Edebiyat Araştırmaları Dergisi: İstanbul, 2010.

ÖzÖN, Mustafa Nihat: Türk Ata Sözleri: İstanbul 1952, İnkılap Kitabevi.

ÖZŞAHIN, Murat: Başkurt Türkçesi Sözlüğü: Ankara 2017, Atatürk Kültür, Dil ve Tarih Yüksek Kurumu Türk Dil Kurumu Yayınları: 1224. Türk Dillerinin Sözlükleri Başkurtça: 11.

ÖzTELLI, Cahit: “Atasözleri Derlemeleri ve Kaynakçaları Üzerine”, Sivas Folkloru: Mayıs 1976, Sayı: 40, 3a-5b.s.

ÖZTELLİ, Cahit: “Kitaplar - Türk Atasözleri (Tenkit)”, Türk Dili: 1 Ekim 1952, Sayı: 13, 44a-50a. s.

PŁaskowicka-Rymkiewicz, Stanisława: "Etat des recherches concernant la parémiographie et la parémiologie turques”, Rocznik Orientalistyczny: Warszawa 1965, XXVIII-2, 59-74. s.

RA'ŪF YEKTĀ: "Muṣāḥabe - Tenḳidāt-ı Mūsỉkiyye”, İḳdām: 15 Cemādiye 'l-evvel 1316 / 1 Teşrīn-i evvel-i

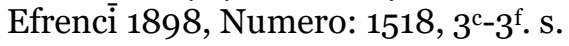

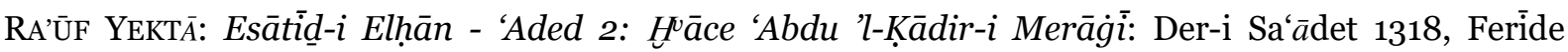
Mațba'ası.

RedHouse, Sir James W.: A Turkish and English Lexicon / Kitāb-ı Ma'ānī-yi Lehce: Constantinople 1890 .

STEINGASS, F.: A Comprehensive Persian-English Dictionary - İncluding the Arabic words and phrases to be met with in Persian literature. - Being Johnson and Richardson's Persian, Arabic, and English Dictionary - Revised, enlarged, and enterly reconstructed.: London 1892.

Ş[EMSE 'D-DĪN] SĀMī: Kạ̄mūs-i Türkì: Der-i Sa‘ādet 1317, I; 1318, II. İḳdām Maṭba'ası. 
ŞEYH SÜLEYMĀN EFENDİ-YI BuHĀRĩ: Luġat-i Çaġatay ve Türki-yi 'Oțmānīi İstanbul 1298, Mihrān Matba'ası.

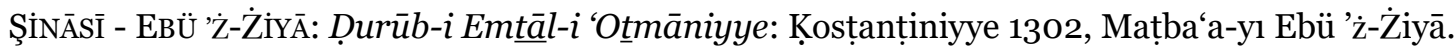

ŞÜKÛN, Ziya: Farsça-Türkçe Lûgat Gencinei Güftar Ferhengi Ziya: İstanbul 1944, I; 1947, II; 1951, III; Millî Eğitim Bakanlığı Yayınları.

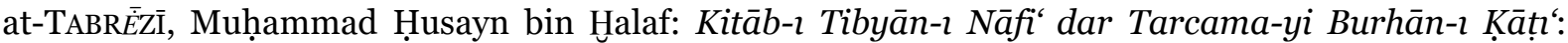
Çeviren: CENĀNĪOĠLI Aḥmed 'Āṣım: Beldetü 'ț-Ṭayyibeti 'l-Ḳosṭanținiyye 1214, Dārü 'ṭ-Ṭıbā'ati 'sSultāniyye.

TEZCAN, Mahmut: Ĕ̆itim Sosyolojisi: Ankara 1992, Bilim Yayınları.

TIETZE, Andreas: Tarihi ve Etimolojik Türkiye Türkçesi Lugatı Cilt 1 A-E: İstanbul-Wien 2002, Simurg 56. Sözlük 2; ... İkinci Cilt F-J: Wien 2009, Österreichischen Akademie der Wissenschaften.

TOPALOĞLU, Bekir - Hayrettin KARAMAN: Arapça-Türkçe Yeni Kamus: İstanbul 2002, Ravza Yayınları.

TOPARLI, Recep - Hanifi VURAL - Recep KARAATLI: Kipçak Türkçesi Sözlüğü: Ankara 2007, Atatürk Kültür, Dil ve Tarih Yüksek Kurumu Türk Dil Kurumu Yayınları: 835.

TÜRK Dil KURUMU: Türkçe Sözlük, 11. Baskı: Ankara 2011, Atatürk Kültür, Dil ve Tarih Yüksek Kurumu Türk Dil Kurumu Yayınları: 549.

TÜRk Díl KuRumu: Türkiye’de Halk Ağzından Derleme Sözlüğü: Ankara 1963, I (A); 1965, II (B); 1968, III (C-Ç); 1969, IV (D); 1972, V (E-F); 1972, VI (G); 1974, VII (H-G); 1975, VIII (K); 1977, IX (LR); 1978, X (S-T); 1979, XI (U-Z); 1982, XII (Ek-I), Türk Dil Kurumu Yayınları - Sayı: 211[/1]-12.

TÜRK Dill KURUmU: XIII. Yüzyıldan Beri Türkiye Türkçesiyle Yazılmış Kitaplardan Toplanan Tanıklarıyla Tarama Sözlüğü: Ankara 1963, I (A-B); 1965, II (C-D); 1967, III (E-Ġ); 1969, IV (KN); 1971, V (O-T); 1972, VI (U-Z); 1974, VII (Ekler); 1977, VIII (Dizin), Türk Dil Kurumu Yayınları - Sayı: 212[/1]-8.

UlUDAĞ, Süleyman: “İbn Haldûn”, Türkiye Diyanet Vakfi İslâm Ansiklopedisi: İstanbul 1999, Cilt: 19, $538^{\mathrm{b}}-543^{\mathrm{c}}$. s. Türkiye Diyanet Vakfı.

ÜLKÜSAL, Müstecib: Dobruca'daki Kırım Türklerinde Atasözleri ve Deyimler: Ankara 1970, Türk Dil Kurumu Yayınları: 306.

ÜLKÜTAŞIR, M. Şakir: "Cumhuriyet Devrinde Folklor Hareketlerine Toplu Bir Bakış”, Türk Dili Belleten: Ankara 1945, Seri: III, Sayı: 4-5, 413-444. s.

ÜLKÜTAŞIR, M. Şakir: Cumhuriyetle Birlikte Türkiye'de Folklor ve Etnografya Çalışmaları: Ankara 1973, Baş̧bakanlık Kültür Müsteşarlığı Cumhuriyetin 50. Yıldönümü Yayınları: 1.

YAVUZ, Hulûsi: “Cerîde-i Mehâkim”, Türkiye Diyanet Vakfi İslâm Ansiklopedisi: İstanbul 1993, Cilt: 7, $408^{c}-409^{b}$. s. Türkiye Diyanet Vakfi. 